\title{
THE GENUS AMENTOTAXUS
}

\author{
HUI-LIN LI
}

Amentotaxus is a coniferous genus, of isolated position, endemic to eastern Asia; there are considerable differences of opinion regarding its proper phylogenetic alliance. The genus has long been considered monotypic. Its species, A. argotaenia (Hance) Pilger, was first proposed as a species of Podocarpus, having been based on sterile material. Later Pilger transferred it to Cephalotaxus (in Engler, Pflanzenr. IV. 5: 104. 1903), but it was subsequently referred to a separate genus by him (in Bot. Jahrb. 54: 41. 1916) because of its very distinct long staminate inflorescences. In Pilger's system of 1926 (Engler \& Prantl, Nat. Pflanzenfam. ed. 2. 13: 267. 1926), Amentotaxus is placed in the Cephalotaxaceae, the only other genus of which is Cephalotaxus. As Amentotaxus is very different from Cephalotaxus, Kudo and Yamamoto (in Jour. Soc. Trop. Agr. Formos. 3: 110. 1931) proposed for it the monotypic family Amentotaxaceae. Florin (Palaeontographica 85, Abt. B: 625-630. 1944; Bot. Gaz. 110: 31-39. 1948), however, is of the opinion that Amentotaxus is not closely related to the Cephalotaxaceae but rather to the Taxaceae. Accordingly, in the latest system of classification of the conifers by Janchen (in Sitz. Oest. Akad. Wiss. Math.-Nat. Kl. Abt. I. 1949(3): 155-162. 1950), it is placed with Torreya in the tribe Torreyeae of the Taxaceae, while Cephalotaxus is considered as representing the monotypic family Cephalotaxaceae. On the basis of both the vegetative and reproductive structures, this disposition is probably the most commendable.

The varied opinions regarding its phylogenetic position show that Amentotaxus is of great morphological interest. Also of considerable interest is its geographical distribution. First discovered around Hongkong and in Kwangtung, in southern China, the genus was subsequently reported to occur in southern Formosa, western Hupeh and Szechuan, southern Yunnan, and Tonkin. These later records all attribute the plants from these widely separated localities to a single species. In all cases, the authors recording these findings have apparently studied only local material, and a comprehensive review of the genus, with specimens representative of all localities, has never been made. Although the number of specimens from the different localities now available is still rather few and in some cases inadequate, apparently due to the plants being of rare occurrence, a study shows that the genus is not monotypic, but is rather composed of several distinct entities, each possessing distinct morphological characteristics and an exclusive as well as isolated and restricted range. In other coniferous genera with similar disjunct ranges, such as Taiwania, the disjunction is found to be specific in nature. Plants of these remote locations have long been isolated and have undergone considerable 
differentiation, so that they are recognizable as morphologically and taxonomically distinct entities, here interpreted as species.

The chief differentiating characters among the species are the size and shape of leaves and the relative width of the stomatal bands. Apparently the number of staminate racemes and the size and shape of the mature seeds are also good taxonomic characters. Unfortunately, as most of the specimens now available are sterile, these latter important characters are not revealed in all species. However, the stomatal bands on the undersurface of the leaves are especially conspicuous and strikingly distinct, especially in combination with other characters, rendering the differentiation of species very certain even when the locality of a given specimen is not indicated. The width of the stomatal bands and the proportion of these to the marginal green bands are very constant among plants of the same general region, that is, of the same species. While only one collection of the genus in Yunnan is so far noted, a larger and more complete series of Formosan specimens is available for study. In all cases, the stomatal bands are of nearly uniform width among plants of the same general range, clearly indicating the taxonomic dependability of this character.

As a result of this study, four species are recognized: one, the type species, occurring in Kwangtung, one in southern Formosa, one in HupehSzechuan, and one in southern Yunnan and possibly also in northern Tonkin. These species all occur at medium to high altitudes, varying from 300 to 1600 meters, in ravines and on rocky cliffs, mostly in shady damp situations or sometimes along borders of streams. They are not only of very restricted range but also of rare occurrence, probably an indication that these ancient plants are on the verge of becoming extinct. As the species are highly ornamental because of their striking foliage, and as they are also of great botanical interest, it would be desirable to exert more effort toward bringing them into cultivation.

The material utilized in this study is deposited at the following herbaria, listed with respective abbreviations used for cited specimens: $\mathrm{AA}=$ Arnold Arboretum; NTU $=$ National Taiwan University, Formosa; $\mathrm{US}=\mathrm{U}$. S. National Herbarium.

I am indebted to the officials of these institutions for permission to study specimens in their care, and to Dr. A. C. Smith, U. S. National Museum, for reading the manuscript and offering suggestions.

\section{Amentotaxus Pilger in Bot. Jahrb. 54: 41. 1916}

Evergreen shrubs or small trees, glabrous, the branchlets opposite, terete or more or less quadrangular, patent or ascending. Leaves persistent toward the upper part of the branchlets, sessile, subsessile, or very shortly petiolate, opposite, coriaceous, decurrent, linear-lanceolate, usually acutish at apex, with a prominent or subprominent costa, green above, with 5 distinct longitudinal bands beneath, the costal and marginal bands pale or silvery green, alternating with 2 broad whitish stomatal bands. Flowers dioecious, on the year's branchlets. Staminate inflorescences of 2-4 
(rarely 1 or 5) spike-like racemes, long and more or less pendulous, short-pedunculate, in the axils of imbricate bracts, the flowers composed of fasciculate stamens of peltate or subpeltate short-stipitate scales, the anther-cells 2-8, ovoid. Ovulate flowers solitary, in the axil of a lateral bract, on short thick to long slender pedicels, the ovule solitary, erect, subtended by minute imbricate scales below. Seeds solitary, large, drupelike, ovoid or ellipsoid, surrounded by a reddish yellow aril open at the apex, subtended by several persistent scales at base.

\section{Type species: Amentotaxus argotaenia (Hance) Pilger.}

Four species in eastern Asia.

As all previous references pertain to a single species, the synonymy given below is adjusted on the basis of the specimens cited or locations attributed. Pilger, the author of the genus, erroneously credited the species Amentotaxus argotaenia (in Engler \& Prantl, Nat. Pflanzenfam. ed. 2. 13: 268. 1926) to western China only, while actually the type locality is in southern China. His description, which is rather brief, is based on composite elements from different localities, the staminate characters on the basis of only one collection, Westland from Taimo Mountains opposite Hongkong, and the ovulate characters on the basis of a single flower from Wilson 3005 from an unspecified locality in western China.

\section{KEY TO THE SPECIES}

A. Stomatal bands white, as broad as or narrower than the outer green marginal bands.

B. Leaves comparatively short, $4-7 \mathrm{~cm}$. long, straight, rarely slightly falcate, acute to obtuse at apex; stomatal bands as broad as the green marginal bands.

1. A. argotaenia.

BB. Leaves longer, $6-11 \mathrm{~cm}$. long, mostly falcate, sometimes straight, longacuminate at apex; stomatal bands about $2 / 3$ as broad as the green marginal bands.

2. A. cathayensis.

AA. Stomatal bands white or brownish, 2 or more times as broad as the outer green marginal bands.

B. Leaves comparatively long and narrow, $5-8.5 \mathrm{~cm}$. long, 7-9.5 mm. broad, mostly slightly falcate, the base acute to obtuse; stomatal bands white, twice as broad as the marginal bands.

3. A. formosana.

BB. Leaves shorter and broader, 3-7 $\mathrm{cm}$. long, 8-11 $\mathrm{mm}$. broad, usually straight; the base broadly acute to subrounded; stomatal bands brownish or yellowish white, 2.5-3 times as broad as the green marginal bands.

4. A. yunnanensis.

1. Amentotaxus argotaenia (Hance) Pilger in Bot. Jahrb. 54: 41. 1916, p. p. (quoted plants from Kwangtung and Hongkong).

Podocarpus argotaenia Hance in Jour. Bot. 21: 357. 1883; Masters in Jour. Linn. Soc. Bot. 26: 547. 1902, p. p.; Dunn \& Tutcher in Kew Bull. Misc. Inf. Add. Ser. 10: 256. 1912. 
Podocarpus insignis Hemsl. in Jour. Bot. 23: 287, 312. 1885.

Cephalotaxus argotaenia Pilger in Engler, Pflanzenr. IV. 5: 104. 1903; Patschke in Bot. Jahrb. 48: 629. 1913.

Shrub, 2-4 m. high; branchlets spreading or sometimes ascending, subterete or quadrangular; leaves thickly coriaceous, subsessile to very shortly petiolate, linear-lanceolate, generally straight, sometimes slightly falcate toward the tip, $4-7 \mathrm{~cm}$. long, $6.5-8.5 \mathrm{~mm}$. broad, acute to obtuse at apex, cuneate at base, slightly revolute at margins, green above, the costa prominent and raised above, scarcely raised beneath, $1-1.5 \mathrm{~mm}$. broad, the stomatal bands whitish to silvery whitish, $1.5-1.8 \mathrm{~mm}$. broad, about as broad as the marginal bands, the marginal bands pale silvery green, 1.3-2 mm. broad; petioles thick, scarcely 1-1.5 mm. long; staminate racemes subterminal or lateral, solitary or 2 or 3 together, in the axils of minute scales, short-pedunculate, more or less pendulous, $5-6.5 \mathrm{~cm}$. long, the flowers composed of subfasciculate peltate or subpeltate stamens, the filaments short, the anther-cells $2-5$, mostly 3 , ovoid; ovulate flowers and mature seeds unknown.

Kwangtung Province at Lofaushan Mountains, and also around Hongkong, in wet rocky situations or along edge of streams, at altitudes of 600-1500 meters.

CHINA: K w a n g t ung : Lofaushan (type locality), Levine $\&$ McClure 704 (US), C. O. Levine 1502 (AA, US). $\mathrm{H}$ o n g k o n g: Lantoa Island, Hongkong Herb. 2068 (AA).

The specimens examined are all sterile. The only staminate specimen known is the type of Podocarpus insignis, Westland $s$. $n$. from Taimo Mountains opposite Hongkong, the basis of descriptions by both Hemsley and Pilger. The type of Podocarpus argotaenia Hance is a sterile specimen of E. Faber, Sept. 1882, from Lofaushan, Kwangtung, in the British Museum (Natural History).

\section{Amentotaxus cathayensis sp. nov.}

Cephalotaxus argotaenia Pilger in Engler, Pflanzenr. IV. 5: 104. 1903, p. p.; Rehder \& Wilson in Sarg. Pl. Wils. 2: 6.1916 (excl. syn.).

Amentotaxus argotaenia Pilger in Bot. Jahrb. 54: 41. 1916, p. p. (quoted plants collected by Wilson), in Engler \& Prantl, Nat. Pflanzenfam. ed. 2. 13: 270. 1926.

Podocarpus argotaenia sensu Masters in Jour. Bot. 41: 269. 1903, in Jour. Linn. Soc. Bot. 37: 414. 1906; non Hance.

Frutex vel arbuscula $2-5 \mathrm{~m}$. alta; ramulis patentibus, teretibus vel quadrangularibus, subcrassis, internodiis ad $1.5 \mathrm{~cm}$. longis; foliis breviter petiolatis, longe lineari-lanceolatis, gracilibus, distincte falcatis, interdum rectis, 6-11 cm. longis, 6-8 mm. latis, superne gradatim attenuatis, apice calloso-acuminatis, basi attenuatis, margine leviter revolutis, costa supra leviter elevata subtus vix elevata circiter $1.5 \mathrm{~mm}$. lata, striis stomatiferis albidis circiter $1.2 \mathrm{~mm}$. latis, latitudine circiter $2 / 3$ striarum marginalium 
aequalibus, striis marginalibus pallidis plus minusve argenteo-viridibus, circiter $2 \mathrm{~mm}$. latis; petiolis crassis 2-3 mm. longis; floribus masculis ignotis; floribus ovulatis (fide Pilger) in axilla bracteae ad basim ramuli foliati enatis, breviter crassiuscule pedicellatis, pedicellis apice squamis imbricatis instructis, ovulo solitario; seminibus maturis ignotis.

Western Hupeh and western Szechuan (?), cliffs of ravines, at altitudes of 300-1100 meters, rare.

CHINA: Western $\mathrm{Ch}$ in a: No precise locality (presumably western Szechuan), E. H. Wilson 3005 (AA, TYPE). S z e c h u a n : Mt. Omei, W. K. Wu 9209 (AA, US). H u p e h : Hsing-shan Hsien, E. H. Wilson 2107 (AA, US).

Only sterile specimens are available. Rehder and Wilson originally indicated Wilson 3005 as an ovulate specimen, but the available one does not bear any flowers. In Pilger's original description of the genus, the ovulate flower is described on the basis of a single flower from Wilson 3005, received through Rehder. In vegetative characters alone, these western Chinese specimens clearly represent a species distinct from those of other regions.

A sterile specimen from Dupha Hills, J. L. Lister in 1874 (AA), has long narrow falcate leaves very similar to those of $A$. cathayensis, but with slightly broader stomatal bands, which are as wide as the marginal bands. This specimen may indicate a more western extension of the range of the species.

\section{Amentotaxus formosana sp. nov.}

Podocarpus argotaenia sensu Henry in Trans. Asiat. Soc. Jap. 24. Suppl: 91. 1896 (List Pl. Formos.) ; Masters in Jour. Linn. Soc. Bot. 26: 547. 1902, p. p.; Matsum. \& Hayata in Jour. Coll. Sci. Tokyo 22: 399. 1906 (Enum. Pl. Formos.); non Hance.

Cephalotaxus argotaenia sensu Forbes \& Hemsl. in Jour. Linn. Soc. Bot. 26: 547. 1907, p. p., non Pilger.

Amentotaxus argotaenia sensu Yamamoto in Bot. Mag. Tokyo 40: 453. 1926, Suppl. Icon. Pl. Formos. 3: 1, t. 1. 1927, op. cit. 5: 7, f. 1-2. 1932, in Jour. Jap. Bot. 8: (64). f. 1-6. 1932; Kanehira in Trans. Nat. Hist. Soc. Formos. 84: 80. 1926, Formos. Trees rev. ed. 33, f. 2. 1936; Kudo in Jour. Soc. Trop. Agr. Formos. 3: 110. 1931; Chen, Ill. Man. Chin. For. Trees \& Shrubs 13, f. 2. 1937; non Pilger.

Arbor vel arbuscula vel frutex ad $10 \mathrm{~m}$. altus, sparse ramosus; ramulis oppositis, patentibus, subteretibus vel subquadrangularibus, internodiis 6-12 mm. longis; foliis subsessilibus vel breviter et crasse petiolatis, lanceolatis, leviter sed distincte falcatis, raro rectis, $5-8.5 \mathrm{~cm}$. longis, 7-9.5 mm. latis, superne gradatim attenuatis, apice calloso-acuminatis, basi acutis vel obtusis, margine revolutis, supra atro-viridibus, costa supra subplana subtus leviter elevata circiter $1.5 \mathrm{~mm}$. lata, striis stomatiferis albidis circiter $2 \mathrm{~mm}$. latis, quam striis marginalibus duplo latioribus, striis marginalibus pallide argenteo-viridibus, circiter $1 \mathrm{~mm}$. latis; petiolis nullis vel crassis vix $1 \mathrm{~mm}$. longis; racemis masculis ad 
apicem ramulorum plerumque 3- vel 4-fasciculatis, raro 5-fasciculatis vel solitariis, gracilibus, circiter $3 \mathrm{~cm}$. longis, breviter pedunculatis, basi squamis coriaceis 2-4-seriatim imbricato-obtectis, squamis plerumque 7 , carinatis, superioribus gradatim majoribus, oblongo-lanceolatis, ad $15 \mathrm{~mm}$. longis et $5 \mathrm{~mm}$. latis, basalibus ovatis ad $5 \mathrm{~mm}$. longis et $3-4 \mathrm{~mm}$. latis, pedunculis circiter $5 \mathrm{~mm}$. longis; floribus masculis subsessilibus, antheris subpeltatis brevistipitatis fasciculatis $1.5 \mathrm{~mm}$. crassis, loculis plerumque $5-8$ pendulis circiter $0.7 \mathrm{~mm}$. longis et $0.5 \mathrm{~mm}$. latis, filamentis brevibus vix $1 \mathrm{~mm}$. longis; floribus ovulatis solitariis lateralibus, subglobosis, circiter $3 \mathrm{~mm}$. crassis, longe pedicellatis, basi squamis circiter 10 minutis opposite imbricato-obtectis, squamis 5-seriatis, carinatis, subaequalibus, circiter $3.5 \mathrm{~mm}$. longis vel latis; ovulo $2 \mathrm{~mm}$. longo et $1.5 \mathrm{~mm}$. crasso, disco parvo cupuliformi carnoso, $2.5 \mathrm{~mm}$. diametro et $1.5 \mathrm{~mm}$. longo; semine maturo solitario axillari, longe pedicellato, oblongo-ellipsoideo, 20-25 mm. longo, 9-11 mm. crasso, apice mucronulato-rostrato, basi squamis minutis persistentibus imbricatis instructo, arillo rubro-luteo, demum atropurpureo; pedicello gracili, $1.5-2 \mathrm{~cm}$. longo.

Southern Formosa (Taiwan), in broad-leaved forests in shady places, near ravines and cliffs, at altitudes of 700-1300 meters, rather scarce.

CHINA: T a iw a n: Taito, Daibu, Taririku, R. Kanehira, May 11, 1924 (AA), R. Kanehira \& S. Sasaki, Feb. 19, 1925 (AA), S. Sasaki, Feb. 25, 1925 (NTU, TYPE), R. Kanehira, Dec. 27, 1925 (AA); Southern Koshun, R. Kanehira in 1924 (AA).

The Formosan plant is better known than plants from the mainland, although it is also more or less rare. It has been described in detail by Yamamoto and others and illustrated by numerous photographs and drawings. The source of the figure given by Chen is not indicated, but it is an exact copy of Kanehira's figure. Chen's generic description also fits only the Formosan plant.

\section{Amentotaxus yunnanensis sp. nov.}

Amentotaxus argotaenia sensu $\mathrm{Hu}$ in Bull. Chin. Bot. Soc. 1(1): 8. 1935, non Pilger.

Arbuscula, ramis crassis, ramulis oppositis, erecto-adscendentibus, gracilibus, teretibus vel subquadrangularibus, internodiis ad $1.3 \mathrm{~cm}$. longis; foliis subsessilibus, linearibus, rectis, raro apicem versus leviter falcatis, 3-7 cm. longis, $8-11 \mathrm{~mm}$. latis, apice obtusis vel acuminatis, basi late acutis vel subrotundatis, margine leviter revolutis, supra viridibus vel pallide viridibus, costa supra prominula elevata subtus subplana vix elevata circiter $1.5 \mathrm{~mm}$. lata, striis stomatiferis leviter fuscis vel luteo-albidis circiter $2.5 \mathrm{~mm}$. latis, quam striis marginalibus 2.5-3-plo latioribus, striis marginalibus pallide argenteo-viridibus ad $1 \mathrm{~mm}$. latis; floribus masculis ovulatisque ignotis; semine maturo pedicellato, ovoideo, circiter $2.2 \mathrm{~cm}$. longo et $1.5 \mathrm{~cm}$. crasso, apice leviter rostrato, arillo rubro-luteo, basi squamis coriaceis 3-seriatim imbricatis instructo, squamis oppositis, circiter 12 , distincte carinatis, superioribus gradatim majoribus ad $4 \mathrm{~mm}$. longis et 
$5 \mathrm{~mm}$. latis, basalibus ovatis ad $2 \mathrm{~mm}$. longis et latis; pedicello crasso, circiter $1.4 \mathrm{~mm}$. longo, in sicco plano.

Southern Yunnan, a moss-clad plant on rocky hill at an altitude of 1600 meters.

CHINA: Y un na n : Makwan, H. T. Tsai 51887, March 2, 1932 (US, Type).

Merrill (in Jour. Arnold Arb. 19: 21. 1938) records Amentotaxus argotaenia from Chapa, Tonkin, basing the record on Pételot 3897. I have not seen specimens of this collection, but judging from the location the plant is probably referable to the Yunnan species, although it may possibly represent $A$. argotaenia, definitely known only from Kwangtung and Hongkong.

Department of Botany,

U. S. National Museum,

SMITHSONIAN Institution,

Washington, D. C. 


\section{$2 \mathrm{BHL}$ Biodiversity Heritage Library}

Li, Hui-Lin. 1952. "The Genus Amentotaxus." Journal of the Arnold Arboretum 33(2), 192-198. https://doi.org/10.5962/p.185813.

View This Item Online: https://www.biodiversitylibrary.org/item/33609

DOI: https://doi.org/10.5962/p.185813

Permalink: https://www.biodiversitylibrary.org/partpdf/185813

\section{Holding Institution}

Missouri Botanical Garden, Peter H. Raven Library

\section{Sponsored by}

Missouri Botanical Garden

\section{Copyright \& Reuse}

Copyright Status: In copyright. Digitized with the permission of the rights holder.

Rights Holder: Arnold Arboretum of Harvard University

License: http://creativecommons.org/licenses/by-nc-sa/3.0/

Rights: https://biodiversitylibrary.org/permissions

This document was created from content at the Biodiversity Heritage Library, the world's largest open access digital library for biodiversity literature and archives. Visit BHL at https://www.biodiversitylibrary.org. 